\title{
EPIPACTIS GREUTERI (ORCHIDACEAE) IN POLAND
}

\author{
Zbigniew SzeląG ${ }^{1}$, Leszek Bernacki, Joanna PaWelec, \\ KRZYSZTOF StaWOWCZYK \& Mateusz Wolanin
}

\begin{abstract}
Between 1997 and 2010, nine localities of Epipactis greuteri H. Baumann \& Künkele were found in the Polish part of the Western Carpathians. Eight of them were confirmed in subsequent years. The distribution of the new species in Poland is mapped. A morphological description of E. greuteri based on specimens from Poland and a key for the Polish Epipactis Zinn species are given.
\end{abstract}

Key words: distribution, Epipactis greuteri, Poland, Western Carpathians

Zbigniew Szelag, Pedagogical University of Cracow, Department of Botany, Podchorążych 2, 30-084 Kraków, Poland; e-mail: azszelag@wp.pl

Leszek Bernacki, Podgórze 12/25, 43-300 Bielsko-Biała,Poland; e-mai:lb.orpol@gmail.com

Joanna Pawelec, Urzad Miasta Jasła, Rynek 12, 38-200 Jasto, Poland; e-mail: joanna_pawelec@poczta.onet.pl

Krzysztof Stawowczyk, Kornatka 154, 32-410 Dobczyce, Poland; e-mail: kstawowczyk@op.pl

Mateusz Wolanin, Department of Botany, University of Rzeszów, Zelwerowicza 4, 35-601 Rzeszów, Poland; e-mail: wolaninm@wp.pl

In August 1997, during field studies of the flora and vegetation of the Barnowiec Nature Reserve in the Beskid Sądecki Mountains (Western Carpathians), Z. Szeląg found an abundant population of Epipactis greuteri H. Baumann \& Künkele. It was the first finding of the species in Poland, which increased the number of Epipactis species in the country to seven (see key below).

In later years, further localities of E. greuteri were discovered in other parts of the Polish Western Carpathians, in chronological order as follows: (1) Beskid Niski Mts, one locality by L. Bernacki and J. Pawelec in 2000; (2) Pogórze Śląskie foothills, one locality by L. Bernacki in 2001; (3) Beskid Sądecki Mts, three localities by K. Stawowczyk in 2007 and 2008; (4) Beskid Makowski Mts, one locality by L. Bernacki and M. Mazur in 2010; and (5) Pogórze Przemyskie foothills, two localities by M. Wolanin in 2010 (Fig. 1).

All discovered localities of E. greuteri in Poland are listed and characterized below.

EG2544 - Beskid SĄDecki Mts, Barnowiec Nature Reserve, Dentario glandulosae-Fagetum, $30 \mathrm{~m}$

\footnotetext{
1 Corresponding author
}

from asphalt road, $650 \mathrm{~m}$ a.s.l., 7 Aug. 1997, Z. Szelag (KRAM).

The Barnowiec Nature Reserve was revisited by ZS in 1998, when three subpopulations of E. greuteri were found in the lower part of the Reserve at 610-830 $\mathrm{m}$ a.s.l. The total population size of E. greuteri in the Barnowiec Nature Reserve in 1998 was estimated to be 40-60 flowering plants, and the estimates were similar in 2000 and 2011. See Table 1 for the phytocoenological characteristics of the E. greuteri occurrence in the Barnowiec Nature Reserve.

EG3414 - Beskid SĄDECKi MTs, Roztoka Mała stream valley, Petasites albus community along stream in forest with Abies alba dominating, $630 \mathrm{~m}$ a.s.l., 1 Aug. 2007, K. Stawowczyk, ca 30 flowering plants observed.

EG2441 - BESKID SĄDECKI MTs, Jaworzynka stream valley near Gołkowice Górne, along forest road at $580 \mathrm{~m}$ a.s.1. and $710 \mathrm{~m}$ a.s.1., 5 Aug. 2008, K. Stawowczyk. In 2011 the locality was visited by KS and LB; 48 flowering plants were observed.

EG2430 - BESKID SĄDECKI MTs, Za Bachnaty stream valley near Gaboń, Abies alba forest along stream, $650 \mathrm{~m}$ a.s.l., a few flowering plants observed, 25 July 2008, K. Stawowczyk.

DF9112 - PoGÓRZe ŚląSKIE FOOTHILls, Wiślicka Skarpa Nature Reserve near Skoczów, on humid margin of Tilio-Carpinetum forest, $290 \mathrm{~m}$ a.s.1., L. Bernacki 12 Aug. 2001, only two flowering plants observed. 


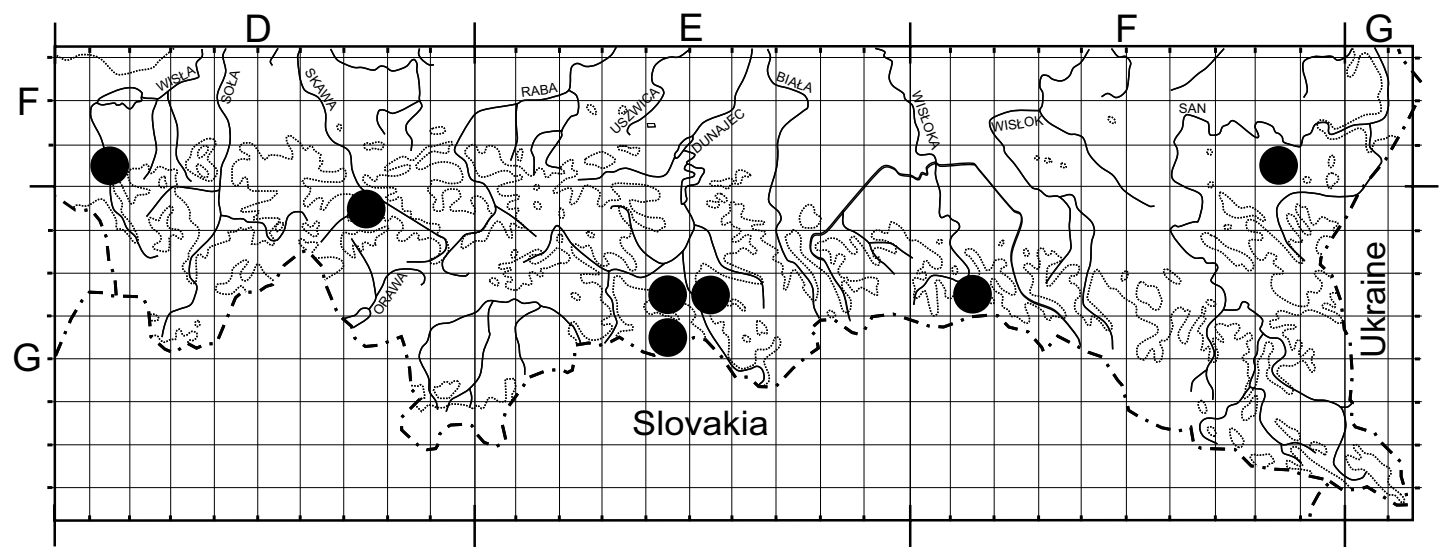

Fig. 1. Distribution of Epipactis greuteri H. Baumann \& Künkele in Poland in ATPOL grid squares $(10 \times 10 \mathrm{~km})$.

In 2007 and 2011, LB searched without results for Epipactis greuteri in the Reserve.

DG0703 - Beskid MAKOwski MTs, Drożdżyna near Budzów, Picea abies-Abies alba forest along stream, 375-390 m a.s.l., 31 July 2010, L. Bernacki \& M. Mazur, ca 25 flowering plants.

FG2101 - BesKID Niski MTs, Magurski National Park, Mt. Góra Kamień, NE slope, 445-455 m a.s.l., in Fagus sylvatica forest, 29 July 2000, J. Pawelec \& L. Bernacki, 21 flowering plants. The occurrence of Epipactis greuteri at the locality was confirmed by JP in 2003, 2006 and 2008.

FF9822 - Pogórze Przemyskie foothils, Góra Frankowa (Maciejówka) hill near Bircza, 440 m a.s.l., in Fagus sylvatica - Abies alba forest, 20 July 2010 M. Wolanin (herb. of Department of Botany, Rzeszów University). In $2011 \mathrm{ca} 20$ flowering plants were found. In 2015, due to the partial deforestation and expansion of Rubus hirtus, only 3 plants were observed.

FF9823 - Pogórze Przemyskie foothils, $1 \mathrm{~km} \mathrm{~S}$ of Chołowice near Krasiczyn, 250 m, Abies alba forest, 21 July 2010, M. Wolanin, 3 flowering plants (herb. of Department of Botany, Rzeszów University).

The taxonomic history of E. greuteri is relatively brief. The species was described in 1981 from the Pindos Mountains in central Greece (Baumann \& Künkele 1981). In the next thirty years E. greuteri was found in Croatia and Slovenia (Robatsch 1988, 1989; Nikolić \& Topić 2005; Jogan 2007), Italy (Savelli et al. 1989; Bongiorni et al. 2006), Austria (Mrkvicka 1992), Czech Republic (Batoušek 1993), Germany (Feldmann et al. 1996), Slovakia (Mered'a 1999,
2000), Bulgaria (Petrova \& Venkova 2008) and Romania (Ardelean 2011).

However, specimens of E. greuteri had been collected in Central Europe for many years before it was described from Greece. For example, in

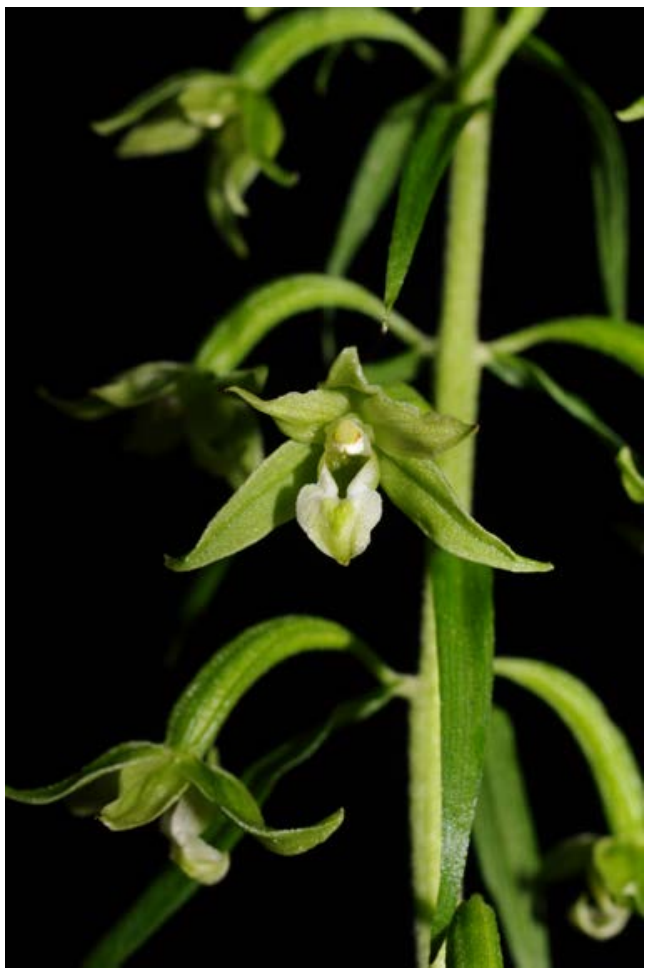

Fig. 2. Epipactis greuteri H. Baumann \& Künkele in the Barnowiec Nature Reserve, 10 August 2011. Photo Z. Szeląg. 


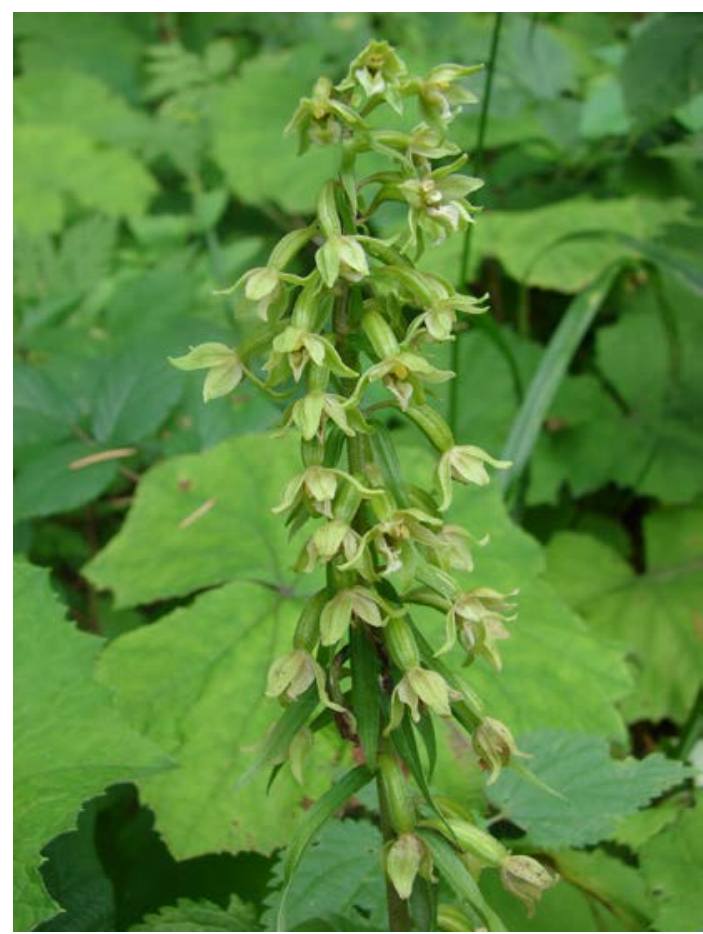

Fig. 3. Epipactis greuteri H. Baumann \& Künkele in the Magurski National Park, 1 August 2007. Photo J. Pawelec.

Slovakia the species was found in 1936 in the Malá Fatra Mts, in 1946 in the Javorníky Mts, and in 1971 in the Pieniny Mts (cf. Mered'a 2000). In the Czech Republic E. greuteri was herbarized in 1884 in the Beskydy Mts and kept in the Silesian Museum in Opava (OP).

\section{Epipactis greuteri H. Baumann \& Künkele}

Figs 2-4

Mitt. Arbeitskreis Heimische Orchid. Baden-Württemberg 13: 344. 1981.

\section{DiSTRIBUTION MAP: Mered'a (2000).}

Stem $20-60(-70) \mathrm{cm}$ high, solitary or in fewspecimen clusters, green to dark green, in lower part glabrous, in upper part with dense whitishgray pubescence. Cauline leaves (3-)5-7 green, oval to lanceolate, acute at apex, $4-10 \mathrm{~cm}$ long and $1.5-3.5 \mathrm{~cm}$ wide; in lower part of stem additional (1-)2-3 brownish, squamous, 1-3 cm long leaves. Inflorescence up to $20 \mathrm{~cm}$ long, with (6-)15-30(-35) autogamic flowers. Bracts
2.0-5.5(-7.0) $\mathrm{mm}$ long, hanging down. Floral pedicels $5-10(-12) \mathrm{mm}$ long. Sepals pale green to yellow-green, oval, acuminate, $10-12(-13) \mathrm{mm}$ long and 5-6 mm wide. Petals whitish to yellowgreenish, occasionally pinkish, ovate, less acuminate, slightly shorter than sepals. Lip 8-10(-11) mm long, divided into two parts. Hypochile cupshaped, nectariferous, greenish, inside green to brownish green with pale margin. Epichile triangular to cordate, whitish with greenish central part, 4.5-6.0 mm long and 4.0-5.5 mm wide, slightly curved down at apex, with two smooth calli at base. Clinandrium strongly reduced. Rostellum with non-functional viscidium. Pollinia friable, easily disintegrating. Ovaries green, nodding on elongated pedicels, moderately pubescent. Capsules yellowish-green. Flowering: end of July and August.

The description is based on plants from the Beskid Sądecki Mountains.

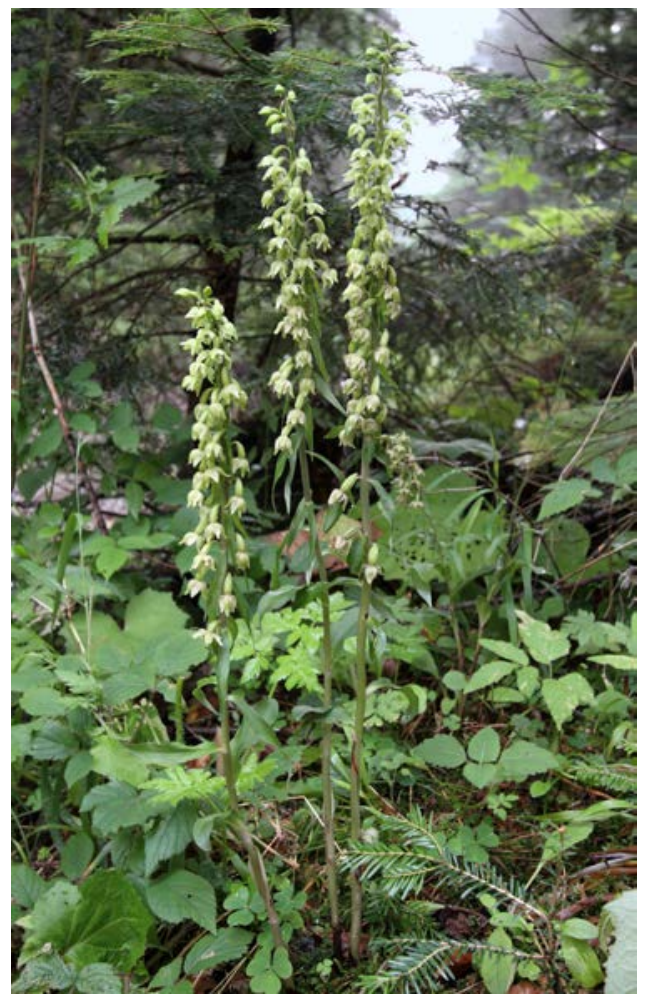

Fig. 4. Epipactis greuteri H. Baumann \& Künkele in the Jaworzynka stream valley, 31 July 2010. Photo M. Fiedor. 
Table 1. Phytocoenological spectrum of the Epipactis greuteri subpopulations in the Barnowiec Nature Reserve, 10 August 2011.

\begin{tabular}{|c|c|c|c|}
\hline Relevé number & 1 & 2 & 3 \\
\hline Relevé area $\left[\mathrm{m}^{2}\right]$ & 400 & 400 & 400 \\
\hline Slope & $\mathrm{N}$ & $\mathrm{NE}$ & $\mathrm{NE}$ \\
\hline Aspect $\left[{ }^{\circ}\right]$ & 10 & 15 & 10 \\
\hline Tree cover [\%] & 90 & 100 & 100 \\
\hline Shrub cover [\%] & 30 & 40 & 40 \\
\hline Herb cover [\%] & 60 & 80 & 60 \\
\hline A. Abies alba & . & 1 & + \\
\hline Fagus sylvatica & 1 & 3 & 4 \\
\hline Picea abies & 3 & + & + \\
\hline B. Abies alba & + & 2 & + \\
\hline Picea abies & + & + & + \\
\hline Fagus sylvatica & 1 & 1 & 3 \\
\hline C. Epipactis greuteri & + & + & + \\
\hline Athyrium filix-mas & + & 1 & + \\
\hline Bromus benekenii & 1 & . & . \\
\hline Circaea intermedia & . & 1 & . \\
\hline Corallorhiza trifida & . & . & + \\
\hline Dentaria bulbifera & 1 & + & + \\
\hline Dentaria glandulosa & 1 & 2 & 2 \\
\hline Dryopteris dilatata & 1 & + & + \\
\hline Dryopteris spinulosa & 1 & . & 1 \\
\hline Festuca sylvatica & . & + & . \\
\hline Galeobdelon montanum & + & 1 & 1 \\
\hline Galium odoratum & . & 1 & 1 \\
\hline Hordelymus europaeus & + & + & . \\
\hline Impatiens noli-tangere & 1 & . & . \\
\hline Mercurialis perennis & 1 & 1 & + \\
\hline Neottia nidus-avis & . & . & + \\
\hline Oxalis acetosella & 1 & . & . \\
\hline Petasites albus & 2 & . & . \\
\hline Polystichum aculeatum & . & + & 1 \\
\hline Viola reichenbachiana & + & + & + \\
\hline
\end{tabular}

\section{Key to The Polish EPIPACTIS SPECIES}

1. Hypochile with two lobes at base ............ $\ldots \ldots \ldots \ldots \ldots \ldots$ E. palustris (L.) Crantz

1. Hypochile unlobed . . . . . . . . . . . 2

2. Cauline leaves 1-3 cm long, shorter than internodes ......... E. microphylla (Ehrh.) Sw.

2. Cauline leaves $>4 \mathrm{~cm}$ long, longer than internodes ...................... 3

3. Epichile with verrucose calli at base $\ldots \ldots \ldots \ldots$ ........... E. atrorubens (Hoffm.) Besser 3. Epichile with smooth calli at base ........ 4
4. Flowers allogamic. Viscidium functional ... 5 4. Flowers autogamic. Viscidium non-functional or absent .................... 6

5. Cauline leaves up to $6(-8) \mathrm{cm}$ long, $1-2$ times longer than internodes, green-purplish $\ldots \ldots \ldots \ldots \ldots$ ................... p. purpurata $\mathrm{Sm}$.

5. Cauline leaves up to $10(-15) \mathrm{cm}$ long, 2-4 times longer than internodes, green .............. . . . . . . . . . . . . E. helleborine (L.) Crantz

6. Bracts spreading. Floral pedicels up to $4-5 \mathrm{~mm}$ long, sepals up to $9(-11) \mathrm{mm}$ long .......... $\ldots \ldots \ldots \ldots$. albensis Nováková \& Rydlo

6. Bracts hanging down. Floral pedicels 5-10(-12) $\mathrm{mm}$ long, sepals 10-12(-13) mm long ....... ........ E. greuteri H. Baumann \& Künkele

Acknowledgements. We thank Dr. Pavol Mered'a jr. (Bratislava) and Dr. Petr Batoušek (Zlín) for confirming the identification of the Epipactis greuteri from Poland and for valuable discussions, and the three anonymous reviewers for helpful remarks and valuable suggestions on the manuscript. LB thanks Marek Mazur (Jachówka near Sucha Beskidzka) for information on the E. greuteri locality and for helping in fieldwork.

\section{REFERENCES}

ARdeleAN C. 2011. Epipactis greuterii (Orchidaceae) a new orchid species for Romanian flora. J. Eur. Orch. 43: 527-534.

BATOUŠEK P. 1993. Epipactis greuteri Baumann \& Künkele in der Tschechischen Republik. Mitteilungsbl. Arbeitskreises Heimische Orchid. Baden-Württemberg 25: 141-145.

Baumann H. \& Künkele S. 1981. Beiträge zur Taxonomie europäischer Orchideenarten. Mitteilungsbl. Arbeitskreises Heimische Orchid. Baden-Württemberg 13: 337-373.

Bongiorni L., De Vito R., Fori S., Pisani G. \& Romolini R. 2006. Epipactis pontica Taubenheim e Epipactis greuteri H. Baumann \& Künkele (Orchidaceae) nuove località per 1'Italia. J. Eur. Orch. 38: 907-916.

Feldmann R., Wucherpfennig W. \& Zaiss H.-W. 1996. Epipactis distans und Epipactis greuteri - zwei für Deutschland neue Orchideenarten. J. Eur. Orch. 28: 108-118.

JoGAN N. 2007. Epipactis Zinn - močvirnica. In: A. MARtinčič, T. Wraber, N. Jogan, A. Podobnik, B. Turk, B. Vreš, V. Ravnik, B. Frajman, S. Strgulc Krajšek, B. TrČAK, T. BAČIČ, M. A. Fischer, K. Eler \& B. Surina (eds), Mala flora Slovenije. Ključ za določanje praprotnic in semenk. Četrta, dopolnjena in spremenjena izdaja, pp. 763-767. Tehniška Založba Slovenije, Ljubljana.

MereĎA P. 1999. Identification key to the species of the genus Epipactis Zinn published from Slovakia. Bull. Slov. Bot. 
Spoločnnost. 21: 131-142 (in Slovak with English summary).

MEREĎA P. 2000. Epipactis greuteri (Orchidaceae) - a new species of the Slovak flora. Biologia (Bratislava) 55: 49-55.

MrkvickA A. C. 1992. Erstnachweis von Epipactis greuteri H. Baumann \& Künkele in Österreich. Mitteilungsbl. Arbeitskreises Heimische Orchid. Baden-Württemberg 24: 450-456.

Nikolić T. \& ToPIĆ J. (eds) 2005: Crvena knjiga vaskularne flore Hrvatske. Ministarstvo Kulture Republike Hrvatske, Državni Zavod za Zaštitu Prirode, Zagreb.

Petrova A. S. \& Venkova D. Y. 2008. Epipactis exilis and E. greuteri (Orchidaceae) in the Bulgarian flora. Phytol. Balcan. 14: 69-73.
RoватsCH K. 1988. Beiträge zur Kenntnis der europäischer Epipactis-Arten (Orchidaceae). Linzer Biol. Beitr. 20: 161-172.

Rоватsсн K. 1989. Beiträge zur Kenntnis der europäischer Epipactis-Arten (Orchidaceae). Linzer Biol. Beitr. 21: 295-302.

Savelli P. R., Alessandrini A. \& Liverani P. 1989. Epipactis purpurata Smith ed E. greuteri $\mathrm{H}$. Baumann et Künkele in Italia, con nuove località di E. persica (Soó) Nannfeldt (Orchidaceae). Arch. Bot. Ital. 64: 192-198. 